\title{
A Comprehensive Index for Measuring Water Security in an Urbanizing World: The Case of Pakistan's Capital
}

\author{
Salman Khan ${ }^{1}$, Yiqing Guan ${ }^{1, *}$, Farhan Khan ${ }^{2}$ and Zeeshan Khan ${ }^{3}$ \\ 1 College of Hydrology \& Water Resources, Hohai University, Nanjing 210098, China; salman@hhu.edu.cn \\ 2 School of Electrical Engineering and Computer Science, National University of Sciences and Technology, \\ Islamabad, Pakistan; farhan.khan@seecs.edu.pk \\ 3 Department of Management Sciences, University of Swabi, Khyber Pakhtunkhwa 23561, Pakistan; \\ shanmir8792@gmail.com \\ * Correspondence: yiqingguan@hhu.edu.cn
}

Received: 10 November 2019; Accepted: 30 December 2019; Published: 6 January 2020

\begin{abstract}
Growing population, increasing urbanization, and rural to urban migration, coupled with the ongoing climate change, threaten the sustainability of cities, particularly in developing countries. Previous studies indicate numerous deficiencies in the water supply and sewage systems of Islamabad; however, a comprehensive insight into the water security assessment has not been carried out. Therefore, this study is aimed at assessing the urban water security of Islamabad by taking both human and environmental aspects into consideration. In principle, we achieve this objective by implementing the Water Security Assessment Framework, using five distinct parameters to calculate an urban water security index. The water supply dimension incorporates availability, accessibility, affordability, and the quality of drinking water in the city, whereas, sanitation and health dimension measures access to improved drainage systems as well as the state of overall hygiene of the city inhabitants. Furthermore, the water economy dimension includes water productivity and investment aspects in the study area, while the environment and ecosystem dimension looks into the current state of natural water bodies. Similarly, overall management and public support for freshwater resources are measured in the society and governance dimension. In general, we attempt to better comprehend water-security nexus in the federal capital considering it as a prerequisite to ensure a sustainable future for the city dwellers.
\end{abstract}

Keywords: water security; Islamabad; climate change; Pakistan; municipal water; urbanization; sustainable cities; sanitation; hygiene

\section{Introduction}

Water security, a concept first emerged in the 1940s, is not only directly associated with food, energy, economic, and environmental security but also plays a pivotal role in ensuring a region's military security [1,2]. Conflicts and riots resulting from water insecurity are particularly widespread in weaker economies, further hampering their economic growth [3]. Water security encompasses water quality, quantity, reliability, equitable access, as well as environmental sustainability of water resources [4]. The United Nations Sustainable Development Goals 2030, presented in 2015, incorporates SDG-6 to "ensure availability and sustainability of water and sanitation for all" [5]. Water resources are not only vital for species survival, but their optimal management is indispensable to improve livelihood, generate wealth, and eradicate poverty [6].

Water insecurity and urbanization are two intersecting global phenomena with significant impacts on people, businesses, and the environment [7]. Nevertheless, achieving water security has been 
an arduous task due to the ever-increasing population, precipitous urbanization and ongoing climate change. Rapid urbanization engenders significant socio-economic and environmental consequences [8]. During the last century, the global human population has more than quadrupled, whereas freshwater withdrawal has increased roughly six times [9-11]. Moreover, the world population is estimated to reach 9.7 billion by 2050, with $68 \%$ living in urban areas [12]. Unprecedented urbanization and overexploitation of resources has reduced the quantity of available freshwater and caused excessive pollution deteriorating the ecosystem [13]. Notably, the issue of a growing population is even more alarming in the developing world, where water supply and sanitation facilities are already inadequate [14].

World Bank 2009 report states that the developing countries are projected to encounter a $70-80 \%$ cost of the total climate change damage [15]. Additionally, the human population in those areas is becoming increasingly urbanized and wealthier [16]. Cities are especially prone to the adverse impacts of climate change and their vulnerability to water-related disaster is increasing [17-19]. Moreover, water demand has also been rising exponentially as a result of population growth and improved living standards in the developing countries, further intensifying the burden on the limited water resources and jeopardizing their sustainability [14]. Surface water temperatures are in close equilibrium with the atmospheric temperature, and any change in the water temperature directly impacts the lifecycle of aquatic organisms [20]. In addition, climate change is believed to affect nutrient loads in the surface waters, hence, escalating eutrophication, and the concentration of heavy metals and other contaminants because of increased industrial and municipal discharges [21].

Pakistan is among the top ten countries most vulnerable to the adverse impacts of climate change [22]. The rise in global temperatures is predicted to alter rainfall patterns over the country, and consequently intensify the frequency and severity of floods and droughts [23]. The nation with over 200 million inhabitants became a water-stressed country in the year 2000 and is predicted to become water-scarce by 2030 [24]. Food and Agriculture Organization's measurements indicate that the country's pressure on its water resources is at a critical level of $74 \%$ in comparison with neighboring India, where this value is estimated to be 34\% [25]. The country's water demand is estimated to increase annually at a rate of $10 \%$, which is projected to reach 338 billion cubic meters by 2025 [26]. However, the country's per capita water availability has fallen from $1700 \mathrm{~m}^{3}$ in 1992 to $1090 \mathrm{~m}^{3}$ in 2012 [27]. Human Development Report (2010) estimates that 10\% of the country's population does not have access to safe drinking water. In terms of drinking water quality, Pakistan lies in the 80th place among the 122 countries studied [28]. Additionally, the country has a capacity to treat a meager amount of less than $8 \%$ of its total wastewater [29], and the majority of untreated sewage is disposed into the water bodies. Waterborne illnesses are not uncommon in the country, with 200,000 children dying every year of diarrhea alone [30].

Owing to the problems related to Pakistan's water resources and urban sustainability, optimum analysis of water security is crucial. In recent decades, numerous conceptual assessment frameworks have been proposed to measure the water security. The national water security index developed by the Asian Development Bank (ADB) analyzes water security performances using five key dimensions covering household, economic, urban, environment, and resilience to water-related disasters aspects of water security [31]. Lautze and Manthrithilake (2012) follow a similar approach to estimate an overall water security index for countries in the Asia Pacific [32]. Nonetheless, the majority of these frameworks are established on regional and national scales which make them less suitable on a local level [33]. Moreover, scaling down water security assessments to a city level can offer additional benefits in the understanding and implementation of the relatively intricate concept [1]. Consequently, researchers have put forward several indices and indicators to analyze water securities in cities around the world.

One such example is the sustainable cities water index, which consists of the resilience, efficiency and quality elements of urban water [34]. To assess the sustainability of an urban water system, Ray and Shaw (2019) propose a water security index incorporating physical, socio-economic, and intuitional dimensions of municipal water systems [35]. Shrestha et al. (2018) use seven dimensions of municipal 
water to calculate a composite index based on a community level metric in Kathmandu Valley. However, their research relies solely on the survey responses of different households in the area [36]. Thapa et al. (2018) calculate the household water security index as the ratio of supply to demand for domestic water. The index was effectively implemented to cover the spatial and temporal variability of urban water security in Kathmandu, Nepal [37]. Jensen and Wu (2018) adopt the process analysis method to establish several indicators primarily focusing on water availability, risks, and governance in Hong Kong and Singapore [7]. Babel et al. (2017) and Aboelenga et al. (2019) propose an all-encompassing urban water security framework that captures social, environmental, economic, and organizational aspects of urban water into account $[33,38]$.

The research presented in this paper follows the urban water security index (UWSI) proposed by Babel et al. (2017) for analyzing urban water security in Islamabad. This index has been previously used in other cities, including Bangkok, Jaipur, Hanoi, and Addis Ababa [38,39]. The index is derived using the DPSIR (drivers-pressures-states-impacts-responses) framework, which was developed by the European Environmental Agency for Integrated Environmental Assessment [40]. UWSI serves as a robust diagnostic tool for highlighting shortcomings in the urban water systems where water managers and policymakers can effectively identify the effects of their strategies. Primarily, UWSI is composed of various dimensions, indicators, and sub-indicators that take into consideration all the drivers, pressures, states, impacts and responses associated with the city's water security (Figure 1) [4]. To this end, each dimension is prudently chosen based on several factors, including but not limited to, its significance, ease of quantification, and data availability. Then, these dimensions are represented in terms of one or more indicators following SMART (specific, measurable, attainable, relevant, and time-bound) criteria. Finally, each indicator is measured with one or more particular variables (sub-indicators). The indicators and their corresponding variables are intended to cover all the dimensions of urban water security, as currently measured in the literature.

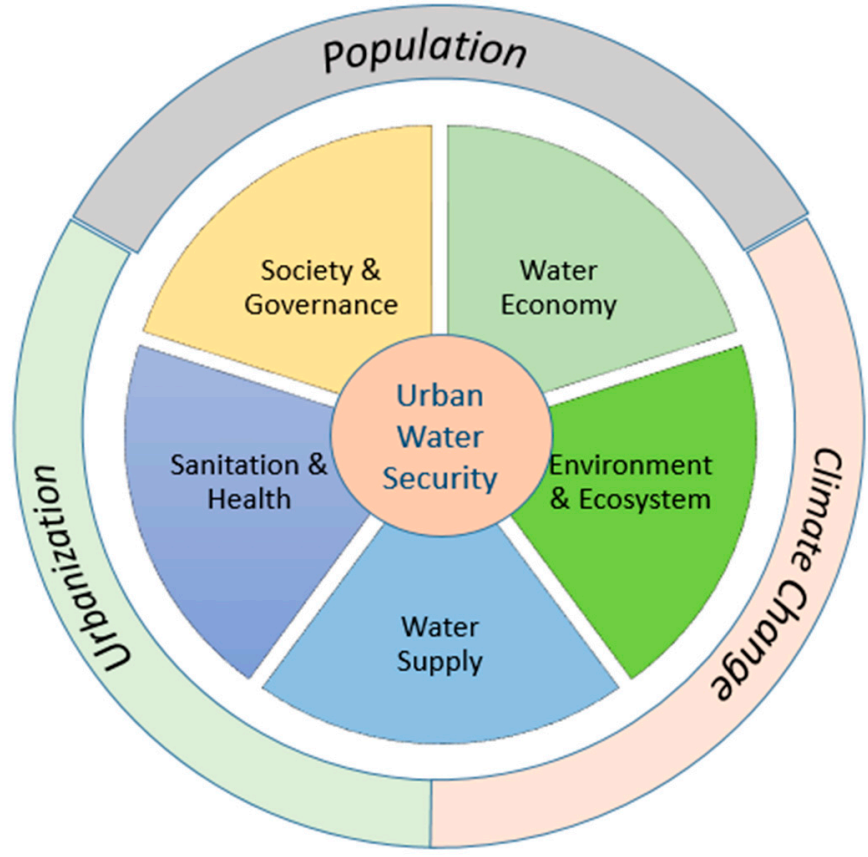

Figure 1. Population, urbanization, and climate change are the major drivers of water (in)security; urban water security index (UWSI) dimensions, their corresponding indicators and variables measure the pressures, state, impacts and responses associated with water security. (Source: Authors). 
This article is organized as follows. Section 2.1 discusses the study area and its current water system in detail; Section 2.2 describes the data used, followed by Section 2.3, where the method to calculate UWSI is demonstrated. Section 3 and its subsections reflect on the results of the current study. A detailed discussion is put forward in Section 4, with a conclusion presented in Section 5.

\section{Materials and Methods}

\subsection{Study Area}

Islamabad, the federal capital and the ninth largest metropolis of Pakistan, is regarded as one of the most developed and prosperous regions in the country. The city covers a total land area of $906 \mathrm{~km}^{2}$, which is divided into five different zones (Figure 2). Zone 1, the most developed and urbanized residential area of the city, is subdivided into several sectors. Islamabad contributes $1 \%$ to the country's total GDP and accounts for $24 \%$ of the total income tax revenue [41]. Despite the fact that the city has a very high human development index of 0.87 , it ranked 193rd among 230 cities according to the Mercer Quality of Living Ranking [41]. Islamabad's population has risen from 0.8 million in 1998 to 2 million in 2017, with the current population density of over 2000 persons $/ \mathrm{km}^{2}$ [42]. The population is estimated to grow at a rate of $5.7 \%$ annually and is projected to reach 4.433 million in the next 30 years [43]. Ever-increasing demand because of the increasing population and the downswing in freshwater resources are posing a serious threat to the city's sustainability [44].

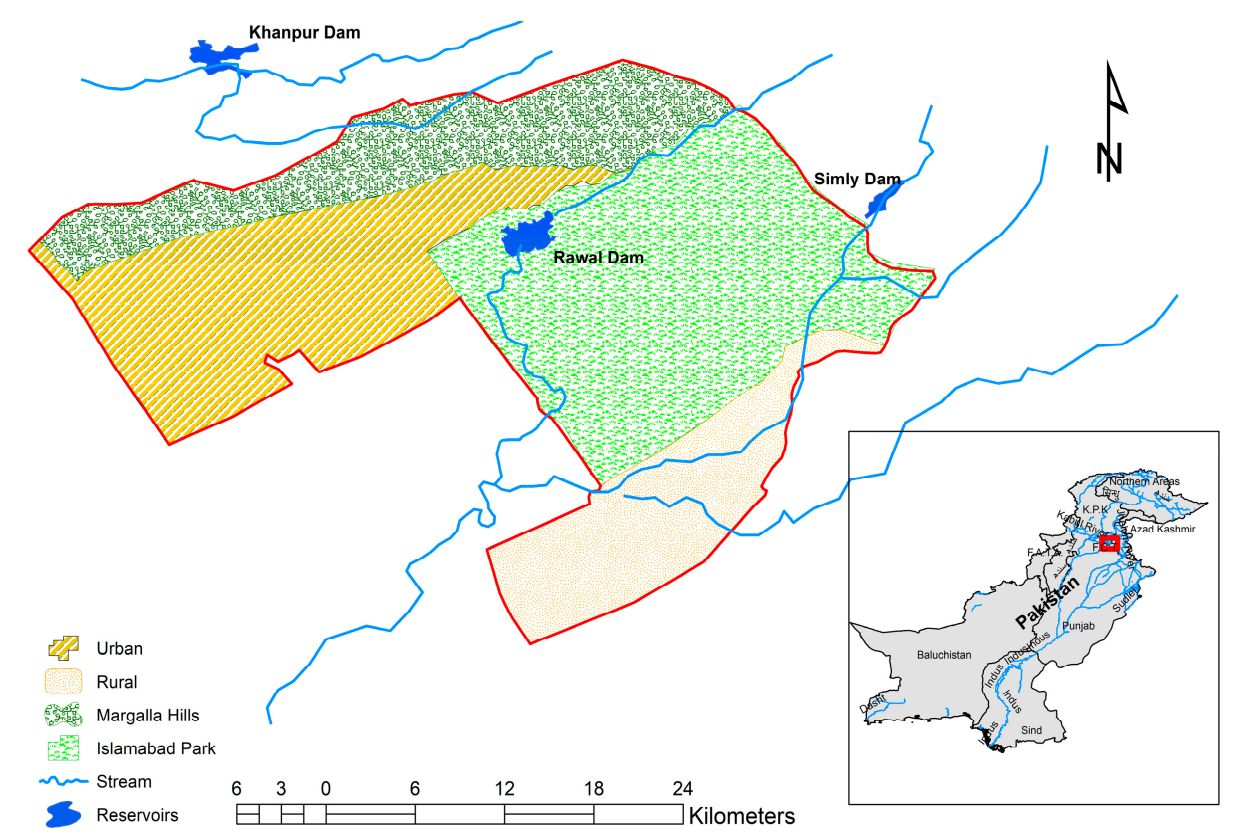

Figure 2. Map of Islamabad (Inset: Pakistan).

The capacity of the Islamabad's surface water resources has been on a constant decline because of the decreased inflow from the upstream as well as the deposition of sediments in the reservoirs. Even more, the water table has been depleting at a staggering rate of $1.7 \mathrm{~m} /$ year due to excessive and unauthorized withdrawal of groundwater. Besides, a water table drawdown of up to $20 \mathrm{~m}$ has been observed in some urban areas of the city [43]. Water table depletion not only deteriorates the ecosystem but also increases the energy consumption of water pumping in an already energy deficient region.

The present water demand for Islamabad is estimated to be more than 475 million liters per day (ML/D); however, only $280 \mathrm{ML} / \mathrm{D}$ is being supplied. The city primarily relies on two reservoirs built in the early 1980s, i.e., Simly and Khanpur Dams, along with headwork water diverted from natural springs located at Saidpur, Shahdara, and Noopur, as well as over 180 tube wells extracting groundwater for its water supply [45]. The municipal water is treated and disinfected at two treatment 
plants, namely Sangjani water treatment plant and Simly water treatment plant with a collective design capacity of $352 \mathrm{ML} / \mathrm{D}$ [46]. The share of groundwater accounts for less than $10 \%$ of the total the city's water supply.

Studies indicate an excessive loss of over 33\% because of leakage and unauthorized use in the domestic water supply systems of Islamabad [47]. Moreover, an effective national policy for the sustainable use of wastewater is virtually non-existent. Conversely, the city has only one functional sewage treatment plant where less than $20 \%$ of Islamabad's sewage is treated before its disposal. Currently, extreme water rationing, particularly in summer months, is being carried out to counterweigh the gap between demand and supply. Despite the city's water supply coverage being $100 \%$, water outage is a common occurrence in Islamabad.

\subsection{Data}

Islamabad's water supply and sanitation systems are overseen and regulated by the Capital Development Authority (CDA). Therefore, data associated with the municipal water supply as well as wastewater generated and treated in the city were obtained from the CDA, whereas data concerning population and number of households were acquired from the Pakistan Bureau of Statistics. Additional data relating to the quality of the domestic water, health of natural water bodies, water productivity, and freshwater availability have been procured from the previously published literature during the past five years (cited in Table 1). These datasets include concentration of residual chlorine, dissolved oxygen (DO), biochemical oxygen demand (BOD), concertation of chromium (Cr), cadmium (Cd), nickel $(\mathrm{Ni})$, and lead $(\mathrm{Pb})$, coliform count, and gross domestic product (GDP). Furthermore, residents' awareness and their enthusiasm and interest in supporting water security have been recorded through a set of questionnaires and interviews from diverse socioeconomic communities of the city.

\subsection{Water Security Index}

The current research employs water security framework developed by Asia-Pacific Network for Global Change Research for water security assessment on a city level [38,39]. The framework entails defining dimensions and indicators, and subsequently measuring these indicators using several variables to calculate UWSI for a city [38]. Urban water security includes the manifestation of improved management and services that are crucial in bolstering sustainable cities. A model city satisfies the water supply and sanitation needs of the communities, supports a productive economy, maintains river health and ecosystem, and builds resilient communities that can adapt to change. Based on this definition, UWSI for the city of Islamabad is measured using five distinct dimensions (Table 1) viz.

1. Water Supply—representing the quality, quantity, access, and affordability of the potable water;

2. Sanitation and health dimension takes citizens' access to the sewage system, status of sewerage, hygiene, and public health into account;

3. Water Economy - relating to water productivity, revenue, and investment in the urban water sector;

4. Environment and Ecosystem-representing the environmental needs of water and the pollution status of natural water bodies;

5. Society and Governance-capturing the social aspect of urban water security pertaining to the overall management and public awareness and interest associated with the water supply and sanitation system.

These dimensions are represented in terms of 11 indicators and their respective variables. Table 1 enlists 22 variables, their sources of data, and how each variable is measured. 
Table 1. Islamabad's urban water security dimensions, indicator, and variables.

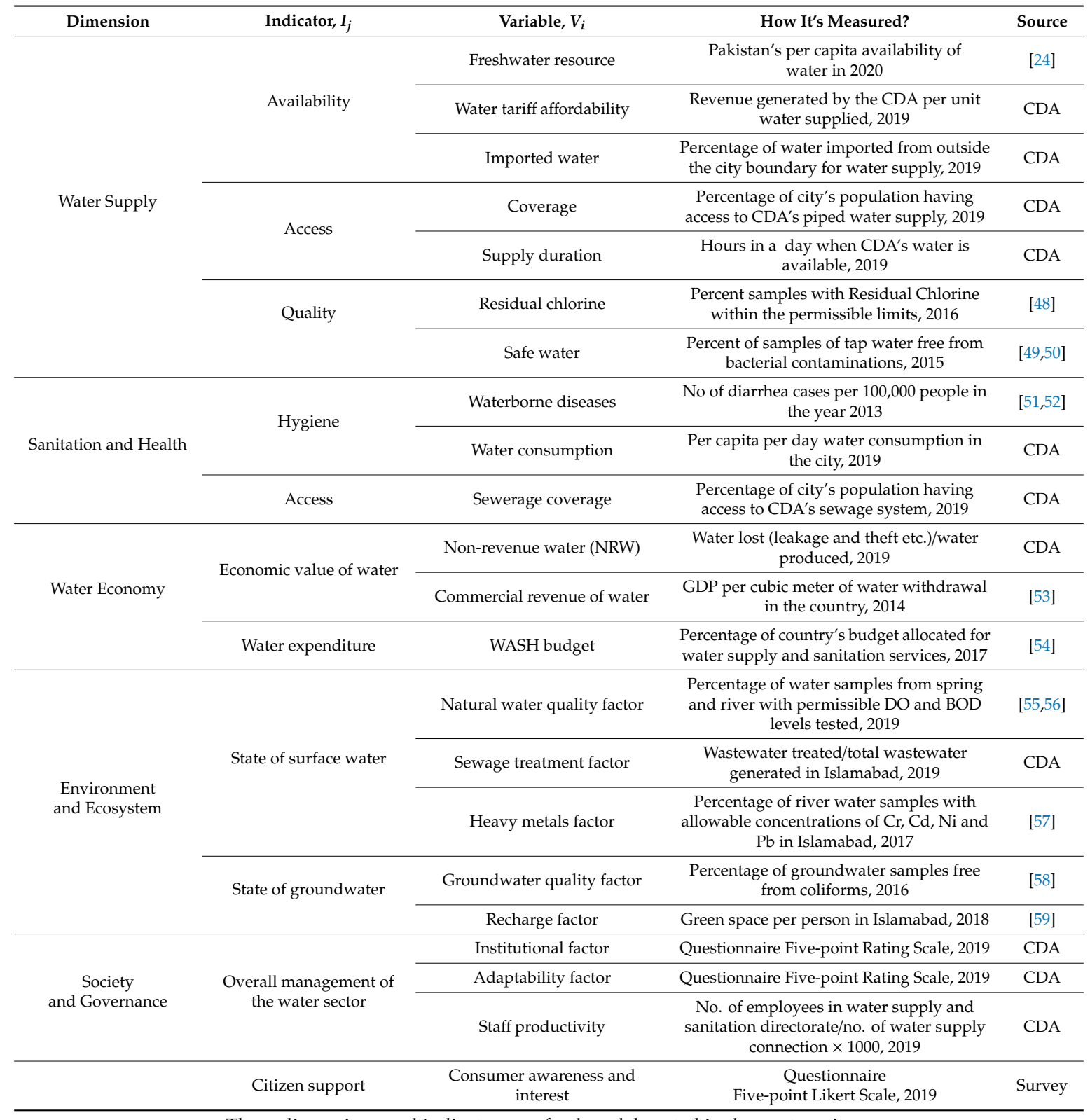

These dimensions and indicators are further elaborated in the next section.

\subsubsection{Water Supply Dimension}

The water supply dimension is represented by three indicators (Table 2), namely availability, access, and the quality of water supplied. Per capita water availability, water tariff affordability, and the ratio of imported water are utilized as variables to calculate the availability indicator. We use Pakistan's per capita water availability estimated by the World Bank to represent the freshwater resource variable for Islamabad [24]. Likewise, water supply coverage (ratio of the population having access to piped water supply) and water supply duration (in hours per day) are used to calculate the second indicator, access. Similarly, the water quality indicator is measured by the percentage of water samples fulfilling drinking water quality standards with respect to bacteriological contamination, and residual chlorine of the water samples collected and tested. 
Table 2. Benchmarking variables for water supply dimension.

\begin{tabular}{|c|c|c|c|c|c|c|c|c|}
\hline \multirow{2}{*}{ Indicator, $I_{j}$} & \multirow{2}{*}{ Variable, $V_{i}$} & \multirow{2}{*}{ Unit } & \multicolumn{5}{|c|}{ Standardization } & \multirow{2}{*}{ Reference } \\
\hline & & & $1 / V_{\min }$ & 2 & 3 & 4 & $5 / V_{\max }$ & \\
\hline \multirow{3}{*}{ Availability } & Freshwater resource & $\mathrm{m}^{3} /$ capita/year & $<500$ & $500-800$ & $800-1000$ & $1000-1700$ & $>1700$ & [33] \\
\hline & Tariff Affordability & US $\$ / \mathrm{m}^{3}$ & $>1$ & 1 & 0.75 & 0.5 & $<0.4$ & [39] \\
\hline & Imported Water & $\%$ & $>60$ & $40-60$ & $40-20$ & $20-10$ & $<10$ & [33] \\
\hline \multirow{2}{*}{ Access } & Coverage & $\%$ & $\leq 60$ & $61-70$ & $71-80$ & $81-90$ & $91-100$ & [31] \\
\hline & Supply duration & Hours/day & $<8$ & $8-16$ & $17-20$ & $21-23$ & 24 & [39] \\
\hline \multirow{2}{*}{ Quality } & Residual Chlorine & $\%$ & $\leq 60$ & $61-70$ & $71-80$ & $81-90$ & $91-100$ & [48] \\
\hline & Safe Water & $\%$ & $\leq 60$ & $61-70$ & $71-80$ & $81-90$ & $91-100$ & {$[49,60]$} \\
\hline
\end{tabular}

\subsubsection{Sanitation and Health Dimension}

Two indicators, namely hygiene and access to the sewage system, are adopted to encompass the sanitation and health dimension (Table 3). The percentage of households connected with the city's drainage system (sewerage coverage) is used as the only variable to represent the access indicator. Additionally, waterborne diseases and per capita water consumption are used as proxy variables to assess the hygiene indicator of Islamabad's urban water security. The number of cases with diarrhea per 100,000 people recorded in the year 2013 was used as a proxy to characterize waterborne diseases in Islamabad.

Table 3. Benchmarking variables for sanitation and health dimension.

\begin{tabular}{ccccccccc}
\hline \multirow{2}{*}{ Indicator, $\boldsymbol{I}_{j}$} & \multirow{2}{*}{ Variable, $\boldsymbol{V}_{\boldsymbol{i}}$} & \multirow{2}{*}{ Unit } & \multicolumn{5}{c}{ Standardization } & \multirow{2}{*}{ Reference } \\
\cline { 3 - 8 } & & & $\mathbf{1 / V _ { \operatorname { m i n } }}$ & $\mathbf{2}$ & $\mathbf{3}$ & $\mathbf{4}$ & $\mathbf{5} / \boldsymbol{V}_{\max }$ & \\
\hline \multirow{2}{*}{ Hygiene } & Waterborne Diseases & No./100,000 people & $\geq 1000$ & $800-500$ & $500-100$ & $100-30$ & $<30$ & {$[39]$} \\
\cline { 2 - 9 } & Water Consumption & Liters/capita/day & $\leq 20$ & $21-50$ & $51-90$ & $91-100$ & $>100$ & {$[61]$} \\
\hline \multirow{2}{*}{ Access } & Sewerage Coverage & $\%$ & $\leq 60$ & $61-70$ & $71-80$ & $81-90$ & $90-100$ & {$[39]$} \\
\hline
\end{tabular}

\subsubsection{Water Economy Dimension}

Pakistan has one of the lowest GDP per cubic meter water withdrawal, even among the developing nations [62]. Thus, this dimension, represented by two indicators economic value of water and water expenditure, is applied to include the productivity aspect of Islamabad's urban water security as well as expenditure relating to the budget allocation for urban water supplies and sanitation (Table 4). The economic value of water in Islamabad is estimated by two separate variables, i.e., NRW (percentage of water lost due to leakage, theft, etc.) and commercial revenue of water (in terms of a proxy variable measured as Pakistan's GPD per cubic meter of freshwater withdrawn). We take Singapore's GDP per cubic meter withdrawal of 1493 US\$ and Madagascar's GDP per cubic meter water withdrawal of 0.58 US $\$$ as the highest and lowest benchmark values respectively [25]. NRW estimates were provided by the CDA. UN Water 2017 report suggests that up to $70 \%$ of Pakistan's water supply and sanitation sector is financed by the government as opposed to household tariffs and billing. Therefore, the country's water and sanitation budget allocation is used as a variable to represent expenditure indicator for the water economy dimension. We use Fiji's highest and Vanuatu's lowest budget allocation for WASH to benchmark this variable [54]. 
Table 4. Benchmarking variables for water economy dimension.

\begin{tabular}{|c|c|c|c|c|c|c|c|c|}
\hline \multirow{2}{*}{ Indicator, $I_{j}$} & \multirow{2}{*}{ Variable, $V_{i}$} & \multirow{2}{*}{ Unit } & \multicolumn{5}{|c|}{ Standardized Score } & \multirow{2}{*}{ Reference } \\
\hline & & & $1 / V_{\min }$ & 2 & 3 & 4 & $5 / V_{\max }$ & \\
\hline \multirow{2}{*}{$\begin{array}{c}\text { Economic Value } \\
\text { of Water }\end{array}$} & Non-Revenue water & $\%$ & $>25$ & $25-20$ & $20-15$ & $15-10$ & $<10$ & {$[63]$} \\
\hline & $\begin{array}{c}\text { Commercial } \\
\text { Revenue of water }\end{array}$ & $\mathrm{US} \$ / \mathrm{m}^{3}$ & 0.58 & - & - & - & 1493 & Authors \\
\hline Water Expenditure & WASH Budget & $\%$ & 0.26 & - & - & - & 3.75 & Authors \\
\hline
\end{tabular}

\subsubsection{Environment and Ecosystem Dimension}

This dimension corresponds to the health of natural water bodies in the study area. Water for the environment and ecosystem dimension is covered by two indicators, i.e., the state of surface water and the state of groundwater. Surface water indicator is evaluated by three separate variables; wastewater treatment factor (volume of sewage treated/total sewage generated), heavy metals factor (percentage of spring/river water samples tested within the allowable limits for $\mathrm{Cd}, \mathrm{Cr}, \mathrm{Ni}$ and $\mathrm{Pb}$ ), natural water quality factor (percentage of samples with acceptable DO and BOD levels). Similarly, the groundwater indicator is measured in terms of groundwater pollution and recharge factors (Table 5). Optimally planned and well managed urban green spaces not only enhance the aesthetics of a city but also provide a favorable habitat to diverse plant and animal species, hence, positively contributing to the overall ecosystem. Urban green spaces have also been recognized to regulate water flows by intercepting runoff and facilitating infiltration. Therefore, we use per capita green space in the city of Islamabad as a proxy variable to assess the groundwater recharge. Researchers recommend a minimum urban green space of $9 \mathrm{~m}^{2}$ per person, and $50 \mathrm{~m}^{2}$ per person for an ideal city [64].

Table 5. Benchmarking variables for environment and ecosystem dimension.

\begin{tabular}{|c|c|c|c|c|c|c|c|c|}
\hline \multirow{2}{*}{ Indicator, $I_{j}$} & \multirow{2}{*}{ Variable, $V_{i}$} & \multirow{2}{*}{ Unit } & \multicolumn{5}{|c|}{ Standardization } & \multirow{2}{*}{ Reference } \\
\hline & & & $1 / V_{\min }$ & 2 & 3 & 4 & $5 / V_{\max }$ & \\
\hline \multirow{3}{*}{$\begin{array}{c}\text { State of } \\
\text { Surface Water }\end{array}$} & $\begin{array}{l}\text { Natural Water } \\
\text { Quality Factor }\end{array}$ & $\%$ & $\leq 60$ & $61-70$ & $71-80$ & $81-90$ & $90-100$ & {$[38]$} \\
\hline & $\begin{array}{c}\text { Sewage } \\
\text { Treatment Factor }\end{array}$ & $\%$ & $\leq 60$ & $61-70$ & $71-80$ & $81-90$ & 90-100 & [39] \\
\hline & Heavy Metals Factor & $\%$ & $\leq 60$ & $61-70$ & $71-80$ & $81-90$ & $90-100$ & Authors \\
\hline \multirow{2}{*}{$\begin{array}{c}\text { State } \\
\text { of Groundwater }\end{array}$} & $\begin{array}{l}\text { Groundwater } \\
\text { Quality Factor }\end{array}$ & $\%$ & $\leq 60$ & $61-70$ & $71-80$ & $81-90$ & $90-100$ & Authors \\
\hline & Recharge Factor & $\mathrm{m}^{2} /$ person & 9 & - & - & - & 50 & Authors \\
\hline
\end{tabular}

\subsubsection{Society and Governance Dimension}

Water security is highly reliant on efficient water governance [2]. The society and governance dimension is estimated by two indicators viz., overall management of the water sector and citizen support for water security. These indicators are further represented by four variables, among which three variables are assessed by questionnaires and surveys (Table 6). Institutional and adaptability factors were analyzed by the questionnaires filled in by the officials of the directorate of water and supply, CDA. Similarly, the consumer awareness and support variable was measured by conducting an online survey of 100 respondents from various socio-economic backgrounds living in the city. Staff productivity is measured in terms of the number of employees in the directorate of water supply and sanitation services per 1000 water connections in the city. Fewer staff member per 1000 connections reflect higher productivity. The value is less than 0.8 in the highest performing developed countries whereas more than 8 in some of the low performing regions [65]. 
Table 6. Benchmarking variables for society and governance dimension.

\begin{tabular}{|c|c|c|c|c|c|}
\hline Indicator, $\boldsymbol{I}_{j}$ & Variable, $V_{i}$ & Unit & $V_{\text {min }}$ & $V_{\max }$ & Reference \\
\hline \multirow{3}{*}{$\begin{array}{c}\text { Overall } \\
\text { Management of } \\
\text { Water Sector }\end{array}$} & Institutional Factor & Five-points rating scale & 1 & 5 & [38] \\
\hline & Adaptability Factor & Five-points rating scale & 1 & 5 & [38] \\
\hline & Staff Productivity & Staff/1000 connections & 8 & 0.8 & {$[65,66]$ Authors } \\
\hline Citizen Support & $\begin{array}{c}\text { Consumer Awareness } \\
\text { and Interest }\end{array}$ & Five-points rating scale & 1 & 5 & {$[38,67]$} \\
\hline
\end{tabular}

\subsubsection{Standardization}

Inevitably, available data on variables are recorded and measured on different scales and have dissimilar units. Therefore, we benchmark each variable on a scale from 1 to $5 ; 1$ represents the lowest level of security, whereas 5 means highly water secure. The benchmarking is carried out on the basis of previous studies (cited in the Reference column of Tables 2-6). For the variables proposed in this study, we use the min-max normalization method for standardization using the following equation,

$$
S_{i}=\left(\frac{V_{i}-V_{\min }}{V_{\max }-V_{\min }}\right)\left(S_{\max }-S_{\min }\right)+S_{\min }
$$

where $V_{i}$ represents the observed value of the variable $i$ for which $V_{\min }$ and $V_{\max }$ are the minimum and maximum possible values respectively. $S_{\min }$ and $S_{\max }$ correspond to the scale maximum and minimum values i.e., 1 and 5. Equation (1) is modified for negative variables $\left(V_{\min }>V_{\max }\right)$ to the following equation,

$$
S_{i}=\left(1-\frac{V_{i}-V_{\min }}{V_{\max }-V_{\min }}\right)\left(S_{\max }-S_{\min }\right)+S_{\min }
$$

Subsequently, each indicator, $I_{j}$ is estimated by calculating the weighted arithmetic mean (Equation (3)) of the standardized score of all the corresponding variables. Likewise, each dimension, $D_{k}$ is computed by taking a weighted arithmetic mean (Equation (4)) of all the indicators in that particular dimension [35].

$$
\begin{aligned}
I_{j} & =\frac{\sum_{i=1}^{n} S_{i} * w_{i}}{\sum_{i=1}^{n} w_{i}} \\
D_{k} & =\frac{\sum_{j=1}^{m} I_{j} * w_{j}}{\sum_{j=1}^{m} w_{j}}
\end{aligned}
$$

where $w_{i}$ and $w_{j}$ are the weights assigned to variables and indicators respectively. However, for the sake of simplification, and because of the insufficiency of necessary data, all variables and indicators are assumed to be of identical impact and significance in this case study and hence, are weighted equally, i.e., $w_{i}=1 / n$ and $w_{j}=1 / m$ [33]. Eventually, scores corresponding to all five dimensions are averaged to calculate the UWSI for the city of Islamabad (Equation (5)).

$$
U W S I=\frac{1}{5} \sum_{k=1}^{5} D_{k}
$$

UWSI scores for the city Islamabad are interpreted based on the grading scale presented in Table 7 [39]. Considering the arithmetic mean and equal impact of all constituent variable can make the UWSI sensitive to outliers, e.g., extremely large or small values. However, since the variables are standardized on a $1-5$ scale, the sensitivity is significantly reduced. It is pertinent to note that given large number of variables and their respective values, a median could be more robust to use for calculating the overall impact of individual factors. However, since our analysis is limited to a single data point having a well-defined set of attributes, i.e., dimensions, indicators, and variables, 
the consideration of more descriptive statistics and in turn the sensitivity analysis falls beyond the scope of this study, at least for the time being.

Table 7. Interpretation of UWSI scores.

\begin{tabular}{|c|c|c|}
\hline UWSI Score & Level of Water Security & Interpretation \\
\hline$<1.5$ & Poor & $\begin{array}{l}\text { The city is incapable to fulfil the basic water needs of } \\
\text { its residents. }\end{array}$ \\
\hline $1.5-2.5$ & Fair & $\begin{array}{l}\text { Almost all dimensions show serious concern. Lack of } \\
\text { proper management of urban water resources }\end{array}$ \\
\hline $2.5-3.5$ & Satisfactory & $\begin{array}{l}\text { A reasonable level of urban water security where } \\
\text { some dimensions require improvement }\end{array}$ \\
\hline $3.5-4.5$ & Good & $\begin{array}{l}\text { The city performs considerably well in most aspects } \\
\text { of water security }\end{array}$ \\
\hline$>4.5$ & Excellent & $\begin{array}{l}\text { An exemplary city with an ideal level of water } \\
\text { security with respect to every dimension }\end{array}$ \\
\hline
\end{tabular}

\section{Results}

UWSI provides an insight into a region's urban water security paradigm. Here, we followed the water security framework approach to obtain a holistic perspective of the current state of domestic water in Pakistan's capital city. Five water security dimensions were carefully selected and were subsequently represented in terms of two or more indicators. We estimated the values of each indicator using several variables standardized on a scale from 1 to 5 . The resulting values, along with their respective standardized scores, are presented in Table 8. Our results reveal a UWSI of 2.8 for Islamabad, indicating that the metropolis has a moderately satisfactory urban water system where various aspects need significant rectifications. We notice that in Islamabad, certain variables of water security scored as high as 5, while others perform very poorly (Table 8 ). The results of these variables are aggregated in Figure 3. The outcomes of water security dimensions in Islamabad are visualized in Figure 4 and their significance is discussed in the following sections.

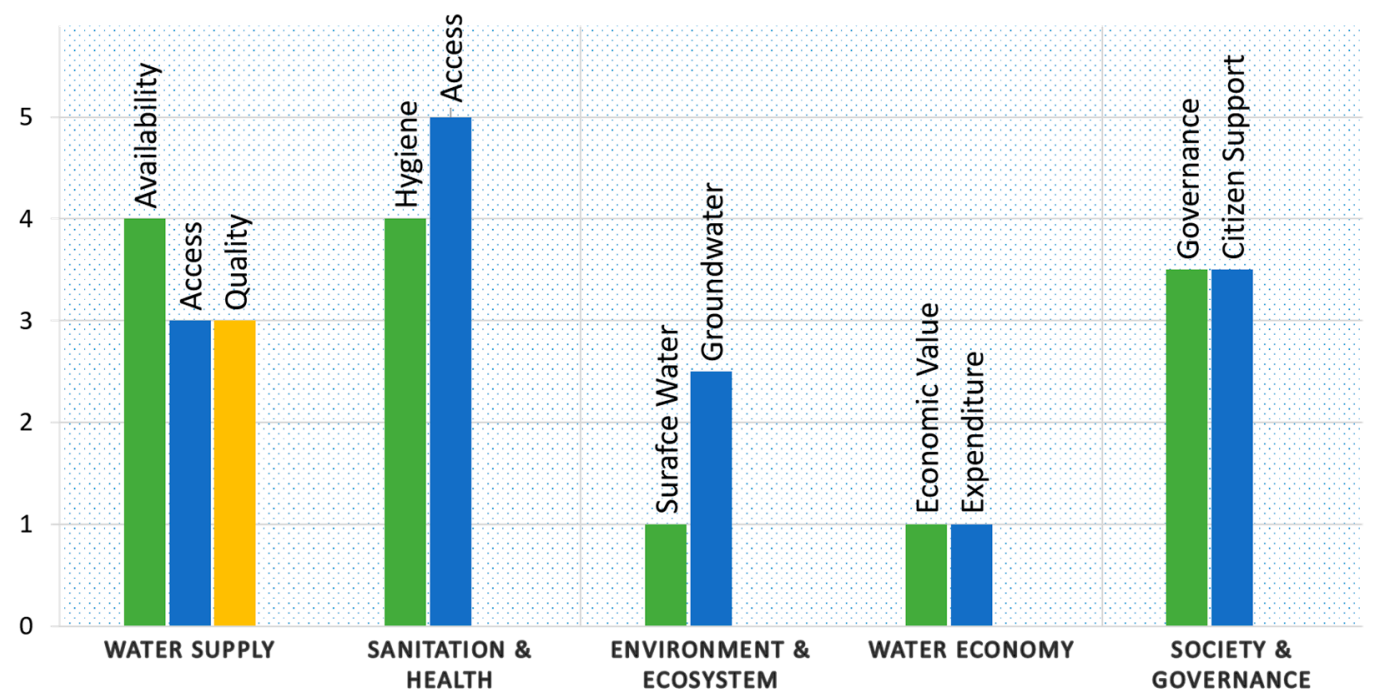

Figure 3. Islamabad's UWSI Indicators. 


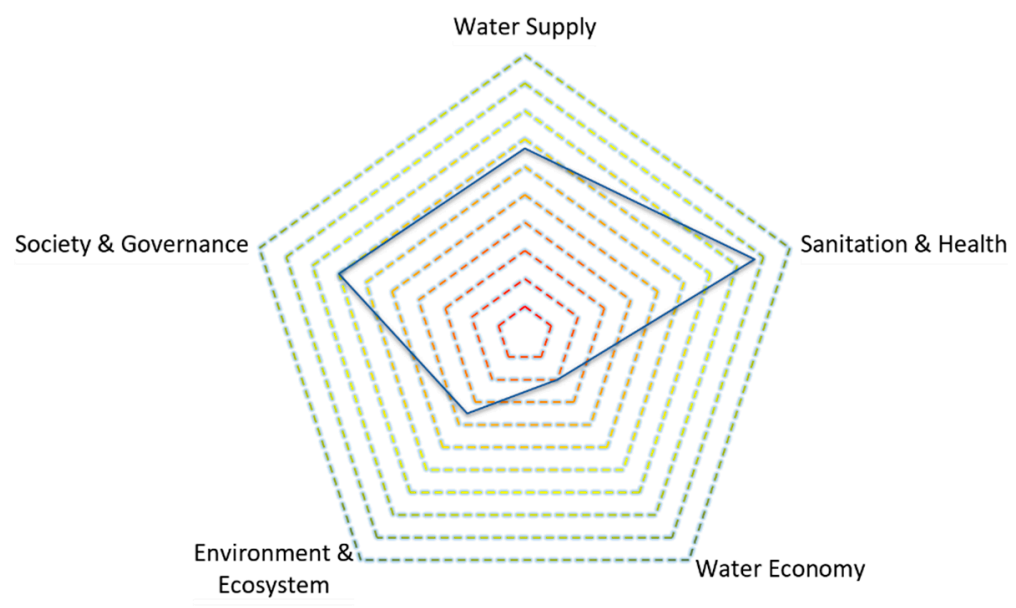

Figure 4. Islamabad's UWSI dimensions.

Table 8. Islamabad's UWSI variables and their scores.

\begin{tabular}{|c|c|c|c|c|}
\hline Dimension & Variable & Unit & Value, $V_{i}$ & Score, $S_{i}$ \\
\hline \multirow{7}{*}{ Water Supply } & Freshwater availability & $\mathrm{m}^{3} / \mathrm{cap}$ & 877 & 3 \\
\hline & Tariff affordability & $\mathrm{USD} / \mathrm{m}^{3}$ & $<0.4$ & 5 \\
\hline & Imported water & $\%$ & 16 & 4 \\
\hline & Water supply coverage & $\%$ & $>90$ & 5 \\
\hline & Supply duration & Hours & 2 & 1 \\
\hline & Residual chlorine & $\%$ & 100 & 5 \\
\hline & Bacteriologically safe water & $\%$ & 60 & 1 \\
\hline \multirow{3}{*}{ Sanitation and Health } & Waterborne diseases & No. & $<200$ & 3 \\
\hline & Per capita water consumption & lpcd & $>150$ & 5 \\
\hline & Population access to sewerage & $\%$ & $>90$ & 5 \\
\hline \multirow{3}{*}{ Water Economy } & Non-revenue water & $\%$ & $>31$ & 1 \\
\hline & Commercial revenue of water & $\mathrm{USD} / \mathrm{m}^{3}$ & 1.12 & 1 \\
\hline & WASH Budget & $\%$ & 0.34 & 1 \\
\hline \multirow{5}{*}{ Environment and Ecosystem } & Streams water quality factor & $\%$ & $<20$ & 1 \\
\hline & Sewage treatment factor & $\%$ & $<50$ & 1 \\
\hline & Heavy metals factor & $\%$ & $<10$ & 1 \\
\hline & Groundwater quality factor & $\%$ & 30 & 1 \\
\hline & Groundwater recharge factor & $\mathrm{M}^{2} /$ person & 40 & 4 \\
\hline \multirow{4}{*}{ Society and Governance } & Institutional factor & \multirow{2}{*}{\multicolumn{2}{|c|}{ Questionnaires }} & 4 \\
\hline & Adaptability factor & & & 3.5 \\
\hline & Staff productivity & Staff/1000 connection & 4.2 & 3 \\
\hline & $\begin{array}{c}\text { Consumer awareness and } \\
\text { interest }\end{array}$ & \multicolumn{2}{|l|}{ Questionnaires } & 3.5 \\
\hline
\end{tabular}

\subsection{Water Supply}

The water supply dimension was estimated using three distinct indicators; water availability, access, and quality. Water availability was measured in terms of freshwater resource, tariff affordability, and imported water. The availability indicator performs sufficiently well as the water tariffs are low; however, Islamabad's reliance on transboundary water and the decrease in the country's freshwater resources are the causes of concern. We also observe that Islamabad's water supply is heavily subsidized 
by the city's government, where citizens are charged, depending on the covered area of their abode, 2.25 to 5.5 US dollars per household per month. These subsidized water tariffs make water very affordable for the city's middle as well as working class residents. The accessibility indicator also performed well as nearly all households are connected with piped water supply. However, it was noted that the water supply connections are not metered; therefore, citizens are not encouraged to conserve the invaluable resource of freshwater. Also, the piped water is supplied for only $2 \mathrm{~h}$ daily, therefore, the residents have to rely on household water tanks to have water accessible around the clock. With regards to water quality, residual chlorine concentrations measured at source at the water treatment plant in Sang-Jani were observed to be in the permissible range in all the samples tested. Nevertheless, nearly $40 \%$ of the total water samples collected from different locations in the city were found to be bacteriologically contaminated with E. coli and fecal coliform. The widespread presence of these contaminants poses a health risk to the city's population, particularly children, elderly, and other immunocompromised individuals.

\subsection{Sanitation and Health}

Sanitation is regarded as an integral aspect of urban water security. Therefore, in this study, we used two dimensions measured by three variables to assess the state of sanitation and health in the study area. It was reported that up to $100 \%$ of the households in the area were connected with the city's municipal sewage system. Moreover, the number of diarrhea cases recorded in a year, and per capita water consumption were used as proxy variables to analyze the hygiene aspect of the sanitation and health dimension. Our results demonstrate that Islamabad has improved water security in terms of sanitation and overall health condition. Despite the bacteriological contamination in the city's drinking water supply, incidences of waterborne diseases in the city were found to be the lowest in the whole country. It may be attributed to the public awareness regarding disinfection through boiling etc. as well as overall hygiene practices of Islamabad's residents. Per capita water consumption, estimated based on the water supplied by the CDA, was found to be satisfactory, indicating improved hygiene.

\subsection{Water Economy}

Islamabad's water security performed very poorly in terms of water productivity. The country, in general, has a very low gross domestic product per unit of freshwater withdrawal. In Islamabad, more than $31 \%$ of the total freshwater produced is lost because of leakage in the piping system, and theft without generating any revenue for the city government. Similarly, unauthorized withdrawal of groundwater through pumping is rampant, particularly in the suburban and rural areas of Islamabad, leading to an excessive drawdown in the water table. Furthermore, none of the water connections are metered, making it impossible for the water supply agencies to accurately assess the city's water needs or monitor its actual consumption. The indicator WASH (water and sanitation hygiene) expenditure explores the government's investment in developing, improving, and maintaining water supply and sanitation infrastructures. Our results indicate that Pakistan has one of the lowest budgets in the world allocated for water supply and sanitation.

\subsection{Environment and Ecosystem}

The environmental aspect of Islamabad's water was found to be ominously unsatisfactory, posing a danger to the citizens' wellbeing, and creating a problematic challenge to maintaining the ecosystem. We observe that springs, lakes, and streams in the study area are heavily polluted with high organic matter concentrations and dangerously low levels of DO. High BOD and low DO levels are a grave danger to the survival of aquatic life in these water bodies. A major portion of the wastewater generated in the city enters the streams without any treatment prior to its disposal. Currently, the city is estimated to produce over $115 \mathrm{ML} / \mathrm{D}$ of sewage per day; however, Islamabad has only one treatment plant of $64 \mathrm{ML} / \mathrm{D}$, which is also not operational to its full capacity. High levels of toxic heavy metals, including $\mathrm{Cd}, \mathrm{Cr}, \mathrm{Ni}$, and $\mathrm{Pb}$, were detected in the freshwater springs in the study area. These heavy metals not 
only impact citizens' health directly through ingestion but also leach into the soil contaminating the groundwater. In addition, the majority of groundwater samples tested were found to be contaminated with coliform. Conversely, Islamabad has an optimum amount of green space per person, providing permeable surfaces that may assist in groundwater recharge in the rapidly urbanizing city. However, it was noted that vegetation cover has declined from $36.48 \%$ in 1993 to $25 \%$ in 2017 because of an accelerated increase in built-up areas [59].

\subsection{Society and Governance}

This dimension measures the overall management of water as well as public awareness and support for water security in the region. We employ four variables to calculate the numerical value of this dimension. Questionnaires designed for the officials of water supply and sanitation directorate of the CDA were used to measure institutional and adaptability factors. Another questionnaire containing six multiple-choice questions was used to measure awareness, support, interest, satisfaction, and enthusiasm of the citizens in achieving and ensuring urban water security. The number of staff members working with the water supply and sanitation division of CDA was used as a variable to assess staff productivity. Islamabad's water supply and sanitation department performs moderately satisfactory in terms of staff productivity. In general, the society and governance dimension shows that Islamabad's water supply and sanitation are managed reasonably well and might be prepared for the upcoming challenges of climate change and population growth. Equally so, the results of anonymous public surveys also indicate that Islamabad's residents are aware of the current problems of water security and are somewhat willing to participate in ensuring its sustainability.

\section{Discussion}

Water security is an emerging new concept that has been receiving extensive consideration of both academicians and policymakers in recent years. It is achieved by providing people with reliable water supplies, and safety from extreme hydrological events, while protecting the natural environment [68]. Nonetheless, population growth, urban sprawl, changing socioeconomics, and ongoing climate change have been the major hurdles in achieving and maintaining water security. Previous researches pertaining to the domestic water supply in Islamabad have pointed out numerous issues in water quality, availability, or management. However, the current study is, to the best of our knowledge, the first attempt to get a comprehensive depiction of the domestic water security by adopting a novel framework formulated by Babel et al. (2017). The framework provides a comprehensive understanding of water supply and sanitation, its governance, and productivity for a city. Previously, it has been successfully implemented in other cities such as Bangkok, Hanoi, Jaipur in Asia, and Addis Ababa in Africa, to measure their urban water security. In terms of water supply and sanitation, Bangkok and Jaipur measure reasonably well while Hanoi and Addis Ababa perform poorly. Hanoi outperforms Bangkok and Jaipur concerning the health of natural water bodies, but shows inferior performance with respect to water governance $[38,39]$. Our results reveal that Islamabad's water supply, sanitation, and governance parameters are comparable to that of Bangkok and Jaipur, and better than Hanoi. However, Islamabad performs significantly worse in terms of water productivity than the three Asian cities studied. Water environment, productivity, and governance aspects of urban water security were not assessed in the case of Addis Ababa.

Our results shed light on both the strengths and weaknesses of the current scenario of the domestic water supply. We observe that there is adequate coverage of piped water supply and drainage systems of the urban households in the city. Besides, low water tariffs make water accessible to the city's economically underprivileged communities. However, there are some significant drawbacks in the current system requiring immediate attention from the authorities. First, the existing water supply may need an upgrade to reduce losses because of leakage and prevent the entry of pathogenic microorganisms into the drinking water supply. In Islamabad, it is not uncommon to see drinking water pipes being laid out in close proximity to the open sewers. More than two-thirds of the water samples 
from both households' taps and filtration plants were found to be bacteriologically contaminated despite the optimum concentration of residual chlorine at source (treatment plant). Ensuring the safety of the tap water will also decrease citizens' reliance on bottled water, therefore, reducing the consumption of single-use plastics. These non-biodegradable, non-recyclable bottles are not only responsible for causing a disproportionate amount of plastic pollution, but their production also contributes to greenhouse gas emissions.

Second, it is noted that the city does not have sufficient capacity to treat its generated wastewater, leading to its untreated disposal. Therefore, authorities must expand the size of wastewater treatment plants to guarantee that $100 \%$ of its sewage is optimally treated before its entry to the water bodies. We anticipate that the treatment of domestic wastewater will not only safeguard the health of natural water bodies, but the resulting effluent can be used to irrigate parks and greenbelts and produce valuable nutrients for the ornamental plants in the city. Additionally, the optimum use of treated wastewater can lower Islamabad's dependency on freshwater, leading to a reduced withdrawal of water resources. Most importantly, the direct disposal of untreated industrial sewage is of particular concern as the high concentration of heavy metals found in industrial wastewater is a serious health risk to its water users.

Currently, Pakistan ranks among the biggest extractors of groundwater, with $6 \%$ of the total withdrawal for domestic use [69]. The exponential upsurge in groundwater extraction because of an increasing demand has led to an imbalance between abstraction and recharge rates in the study area. In Islamabad, the water table has dropped from $12 \mathrm{~m}$ in 1986 to $35 \mathrm{~m}$ in 2015, and a further drop of $11 \mathrm{~m}$ is anticipated by 2025 [58]. Driven by an unprecedented urban expansion, vegetation and barren lands are replaced by impervious built-up areas, thus, hindering groundwater recharge. In addition, the presence of total coliform in nearly two-thirds of the groundwater samples indicates possible infiltration of domestic sewage.

Water resource management is closely linked with economic growth and poverty alleviation. ADB 2016 report indicates that nearly 1\% of the world's GDP is lost because of water insecurity [31]. Pakistan's financial resources and budget allocations for water supply and sanitation have been deemed insufficient to meet its national targets [54]. It is noted that Islamabad, and the whole country in general, performs very poorly in terms of water economy. Moreover, the country is estimated to bear an annual cost of $\$ 0.75$ million because of diarrhea alone, which can be minimized significantly by improving drinking water quality [70].

To promote water conservation, we recommend that all connections must be metered, and the consumers must be charged according to their actual water usage as opposed to the current flat-rate tariff system. Moreover, water conservation practices on a household level, such as recycling and rainwater harvesting, must be incentivized to garner public interest. CDA may consider revising and increasing water prices, particularly for the affluent communities of Islamabad, to compensate for the additional cost of system upgradation and expansion. Additionally, the authority may implement Smart Water Management using Information and Communication technology to monitor and resolve water-related issues through real-time automated data. This state-of-the-art technology has already been in operation for the past few years in Bhalwal, Pakistan [71]. An integrated approach toward urban water management, that entails corresponding development and management of surface, ground and recycled water resources while safeguarding the environment, must be followed to combat the challenges posed by urban sprawl and climate change [72].

The present research has been an attempt to gain a holistic depiction of the current state of water security in the study area. Our study deduces that UWSI is generic and adaptable in nature and can be implemented in other similar cities around the world. In addition, it can be used as an assistive tool for efficiently managing urban water systems. Nevertheless, there are some shortcomings and constraints because of limited data and insufficient financial resources. For example, each variable selected to represent a specific aspect of Islamabad's urban water has been regarded as equal, and its significance could not be determined according to its actual impact. Moreover, estimating the precise 
groundwater resource, its withdrawal, and recharge, was a challenge because of the insufficiency of relevant data. It is also pertinent to mention that we assumed Pakistan's national per capita water resource availability, water productivity, and WASH investment to be homogenous throughout the country. Therefore, national values of these parameters were used to represent the corresponding variables in the study area. The accuracy of urban water security assessment can be improved by measuring local values of all the variables employed.

\section{Conclusions}

This study provides an insight into the current state of urban water security of the city from various perspectives, including water availability, quality, access, affordability, and management. We followed the city-scale water security assessment framework to estimate an index representing the water security in Islamabad metropolis. Our results reveal that Islamabad has a cumulative UWSI of 2.8 , indicating that the city has a moderately satisfactory system and environment to facilitate water security, however, some dimensions of water security require a prompt and vigorous intervention from the authorities.

Islamabad measures reasonably well in terms of water supply and sanitation dimensions showing that the majority of the population has access to adequate water and sanitation services. However, the presence of pathogens in nearly half of Islamabad's tap water is a cause of concern. Furthermore, Islamabad measures very poorly in terms of water for the environment as most of the city's sewage is disposed of to the natural streams without any treatment. Water productivity appears to be another weak aspect sabotaging the city's water security as practically one-third of the water produced, treated, and supplied is lost due to the excessive leakage in the piping system. Nevertheless, water governance is a favorable dimension of Islamabad's water security, where the institutions have laws and policies in place and are continually striving to enhance water security by adopting improved technologies. Islamabad's residents are also positively aware of water-related issues and demonstrate a reasonable inclination towards supporting water security.

Author Contributions: Conceptualization, S.K.; methodology, all authors; validation, S.K., Y.G., and F.K.; formal analysis, S.K.; investigation, S.K.; resources, Y.G.; data curation, Z.K.; writing-original draft preparation, S.K.; writing-review and editing, S.K. and F.K.; visualization, S.K. and Z.K.; supervision, Y.G.; project administration, Y.G.; funding acquisition, Y.G. All authors have read and agreed to the published version of the manuscript.

Funding: This research was financially supported by the National Natural Science Foundation of China, grant number NSFC51579067.

Acknowledgments: The authors would like to thank the directorate of water supply and sanitation of the Capital Development Authority, Islamabad for providing the data. We would also like to thank the anonymous reviewers whose comments and suggestions significantly improved the quality of this manuscript. The first author would also like to extend his gratitude to the Higher Education Commission of Pakistan for financing his studies.

Conflicts of Interest: The authors declare no conflict of interest.

\section{References}

1. Cook, C.; Bakker, K. Water security: Debating an emerging paradigm. Glob. Environ. Chang. 2012, $22,94-102$. [CrossRef]

2. Bolognesi, T.; Kluser, S. Water Security as a Normative Goal or as a Structural Principle for Water Governance. In A Critical Approach to International Water Management Trends: Policy and Practice; Bréthaut, C., Schweizer, R., Eds.; Palgrave Macmillan: London, UK, 2018; pp. 201-231.

3. Almer, C.; Laurent-Lucchetti, J.; Oechslin, M. Water scarcity and rioting: Disaggregated evidence from Sub-Saharan Africa. J. Environ. Econ. Manag. 2017, 86, 193-209. [CrossRef]

4. Gerlak, A.K.; House-Peters, L.; Varady, R.G.; Albrecht, T.; Zúñiga-Terán, A.; de Grenade, R.R.; Cook, C.; Scott, C.A. Water security: A review of place-based research. Environ. Sci. Policy 2018, 82, 79-89. [CrossRef]

5. Van Engelenburg, J.; Van Slobbe, E.; Hellegers, P. Towards sustainable drinking water abstraction: An integrated sustainability assessment framework to support local adaptation planning. J. Integr. Environ. Sci. 2019, 16, 89-122. [CrossRef] 
6. Grey, D.; Sadoff, C.W. Sink or Swim? Water security for growth and development. Water Policy 2007, 9, 545-571. [CrossRef]

7. Jensen, O.; Wu, H. Urban water security indicators: Development and pilot. Environ. Sci. Policy 2018, 83, 33-45. [CrossRef]

8. Roth, D.; Khan, M.S.A.; Jahan, I.; Rahman, R.; Narain, V.; Singh, A.K.; Priya, M.; Sen, S.; Shrestha, A.; Yakami, S. Climates of urbanization: Local experiences of water security, conflict and cooperation in peri-urban South-Asia. Clim. Policy 2018, 19, S78-S93. [CrossRef]

9. Martina, F.; Ellen, K.; Ilona, B.; Stephanie, E.; Florian, W.; Joseph, A. Domestic and industrial water uses of the past 60 years as a mirror of socio-economic development: A global simulation study. Glob. Environ. Chang. 2013, 23, 144-156.

10. Aus der Beek, T.; Flörke, M.; Lapola, D.M.; Schaldach, R.; Voß, F.; Teichert, E. Modelling historical and current irrigation water demand on the continental scale: Europe. Adv. Geosci. 2010, 27, 79-85. [CrossRef]

11. Alcamo, J.; DÖLl, P.; Henrichs, T.; Kaspar, F.; Lehner, B.; RÖSch, T.; Siebert, S. Development and testing of the WaterGAP 2 global model of water use and availability. Hydrol. Sci. J. 2003, 48, 317-337. [CrossRef]

12. Nations, U. World Urbanization Prospects 2018; Department of Economic and Social Affairs, Population Division: New York, NY, USA, 2019.

13. Padowski, J.C.; Gorelick, S.M.; Thompson, B.H.; Rozelle, S.; Fendorf, S. Assessment of human-natural system characteristics influencing global freshwater supply vulnerability. Environ. Res. Lett. 2015, 10, 104014. [CrossRef]

14. Bogardi, J.J.; Dudgeon, D.; Lawford, R.; Flinkerbusch, E.; Meyn, A.; Pahl-Wostl, C.; Vielhauer, K.; Vörösmarty, C. Water security for a planet under pressure: Interconnected challenges of a changing world call for sustainable solutions. Curr. Opin. Environ. Sustain. 2012, 4, 35-43. [CrossRef]

15. Bank, W. World Development Report 2010: Development and Climate Change; World Bank: Washington, DC, USA, 2010.

16. Turral, H.; Burke, J.; Faurès, J.-M. Climate Change, Water and Food Security; Food \& Agriculture Organiztion of the United Nations: Rome, Italy, 2011.

17. Dalby, S. Climate Change: New Dimensions of Environmental Security. RUSI J. 2013, 158, 34-43. [CrossRef]

18. Bolognesi, T. The water vulnerability of metro and megacities: An investigation of structural determinants. Nat. Resour. Forum 2015, 39, 123-133. [CrossRef]

19. Hoekstra, A.Y.; Buurman, J.; van Ginkel, K.C.H. Urban water security: A review. Environ. Res. Lett. 2018, 13, 053002. [CrossRef]

20. EEA. Climate Change and Water Adaptation Issues; European Environment Agency: Luxembourg, 2007.

21. Whitehead, P.G.; Wilby, R.L.; Battarbee, R.W.; Kernan, M.; Wade, A.J. A review of the potential impacts of climate change on surface water quality. Hydrol. Sci. J. 2009, 54, 101-123. [CrossRef]

22. David, E.; Hutfils, M.-L.; Winges, M. Who Suffers Most from Extreme Weather Events. In Think Tank $\mathcal{E}$ Research; GermanWatch: Bonn, Germany, 2019.

23. Khan, S.; Alvarez, L.C.M.; Wei, Y. Sustainable Management of Municipal Solid Waste under Changing Climate: A Case Study of Karachi, Pakistan. Asian J. Environ. Technol. 2018, 2, 23-32.

24. William, J.Y.; Arif, A.; Tousif, B.; Edoardo, B.; Stephen, D.; William, R. Pakistan: Getting More from Water; World Bank: Washington, DC, USA, 2019.

25. FAO. AQUASTAT Database. 2018. Available online: www.fao.org/nr/water/aquastat/main/index.stm. (accessed on 17 April 2018).

26. Mustafa, D.; Akhter, M.; Nasrallah, N. Understanding Pakistan's Water Security Nexus; U.S. Institute of Peace: Washington, DC, USA, 2013.

27. Kamal, S.; Amir, P.; Mohtadullah, K. Development of Integrated River Basin Management for Indus Basin; World Wildlife Fund: Lahore, Pakistan, 2012.

28. Azizullah, A.; Khattak, M.N.K.; Richter, P.; Häder, D.-P. Water pollution in Pakistan and its impact on public health-A review. Environ. Int. 2011, 37, 479-497. [CrossRef]

29. Murtaza, G.; Zia, M.H. Wastewater Production, Treatment and Use in Pakistan; Institute of Soil and Environmental Sciences, University of Agriculture: Faisalabad, Pakistan, 2012.

30. IUCN. Assessment of Water Supply and Sanitation Situation in E and F Sectors and Slum Areas (within or around E and F Sectors) in Islamabad; International Union for Conservation of Nature: Islamabad, Pakitan, 2015; p. 27. 
31. Bank, A.A.D. Asian Water Development Outlook 2016: Strengthening Water Security in Asia and the Pacific; Asian Development Bank: Manila, Philippines, 2016; p. 136.

32. GWP. Assessing Water Security with Appropriate Indicators; Global Water Partnership: Stockholm, Sweden, 2014.

33. Aboelnga, H.T.; Ribbe, L.; Frechen, F.-B.; Saghir, J. Urban Water Security: Definition and Assessment Framework. Resources 2019, 8, 178. [CrossRef]

34. Arcadis. Sustainable Cities Water Index: Which Cities Are the Best Placed to Harness Water for Future Success; Arcadis: Amsterdam, The Netherlands, 2015.

35. Ray, B.; Shaw, R. Developing Water Security Index for Urban Areas. In Urban Drought; Ray, B., Shaw, R., Eds.; Springer: Singapore, 2019; pp. 53-68.

36. Shrestha, S.; Aihara, Y.; Bhattarai, A.P.; Bista, N.; Kondo, N.; Futaba, K.; Nishida, K.; Shindo, J. Development of an objective water security index and assessment of its association with quality of life in urban areas of developing countries. SSM Popul. Health 2018, 6, 276-285. [CrossRef]

37. Thapa, B.R.; Ishidaira, H.; Pandey, V.P.; Bhandari, T.M.; Shakya, N.M. Evaluation of Water Security in Kathmandu Valley before and after Water Transfer from another Basin. Water 2018, 10, 224. [CrossRef]

38. Babel, M.S.; Shinde, V.R.; Sharma, D.; Dang, N. Developing an Operational Water Security Assessment Framework for Application in Diverse Regions of Asia; Asia-Pacific Network for Global Change Research: Kobe, Japan, 2017; p. 104.

39. Assefa, Y.; Babel, M.; Sušnik, J.; Shinde, V. Development of a Generic Domestic Water Security Index, and Its Application in Addis Ababa, Ethiopia. Water 2018, 11, 37. [CrossRef]

40. Kristensen, P. The DPSIR Framework. In Proceedings of the Workshop on a Comprehensive/Detailed Assessment of the Vulnerability of Water Resources to Environmental Change in Africa Using River Basin Approach, Nairobi, Kenya, 27-29 September 2004.

41. SPDC. Social Development in Pakistan; Social Policy \& Development Center: Karachi, Pakistan, 2001 ; p. 244.

42. PBS. Press Release on Provisional Summary Results of 6th Population and Housing Census; Government of Pakistan: Islamabad, Pakistan, 2017.

43. Rashid, O.; Awan, F.M.; Ullah, Z.; Hassan, I. Rainwater harvesting, a measure to meet domestic water requirement; a case study Islamabad, Pakistan. IOP Conf. Ser. Mater. Sci. Eng. 2018, 414, 12018. [CrossRef]

44. Naqvi, S.T.Z.; Khan, A.; Khalid, S.; Rehman, Z.; Khurshid, O.; Siddique, S.; Wahid, A.; Haider, A. Impact of Climate Change on Water Resources of Islamabad: An Integrated Urban Water Resources Management Approach. Lasbela Univ. J. Sci. Technol. 2017, 4, 93-99.

45. Shabbir, R.; Ahmad, S.S. Water resource vulnerability assessment in Rawalpindi and Islamabad, Pakistan using Analytic Hierarchy Process (AHP). J. King Saud Univ. Sci. 2016, 28, 293-299. [CrossRef]

46. Ali, A.; Hashmi, H.N.; Baig, N.; Iqbal, S.; Mumtaz, K. Performance evaluation of the water treatment plants of Islamabad-Pakistan. Arch. Environ. Sci. 2012, 6, 111-117.

47. Ahmad, S. Domestic Water Supply for Islamabad-Future Challenges; Water Resources Research Institute, National Agricultural Research Centre: Islamabad, Pakistan, 2010.

48. Pervez, S. Sang-Jani Water Treatment Plant Islamabad, Pakistan; Network on Water Technology in Asia and Pacific: Tokyo, Japan, 2016; p. 9.

49. WHO. Guidelines for Drinking-Water Quality; World Health Organization: Geneva, Switzerland, 2011.

50. Ahmed, T.; Imdad, S.; Butt, N.M. Bacteriological assessment of drinking water of Islamabad Capital Territory, Pakistan. Desalin. Water Treat. 2015, 56, 2316-2322. [CrossRef]

51. Unit H.I.M. Pakistan: Diarrheal Cases, Diarrheal Rapid Response Units. 2013. Available online: https://www. who.int/hac/crises/pak/sitreps/pakistan_sitrep_19august2013_map.pdf?ua=1 (accessed on 1 October 2019).

52. Baig, M.A.L. Using Geographical Information Systems in Epidemiology: Mapping E Analyzing Occurrence of Diarrhea in Urban-Residential Area of Islamabad, Pakistan; Department of Physical Geography and Ecosystem Science, Lund University: Lund, Sweden, 2017.

53. AQUASTAT. FAO's Information System on Water and Agriculture. 1999. Available online: https://lccn.loc. gov/2004616053 (accessed on 1 October 2019).

54. UN-Water. UN-Water Global Analysis and Assessment of Sanitation and Drinking-Water. In Financing Universal Water, Sanitation and Hygience under the Sustainable Development Goals; World Health Organization: Geneva, Switzerland, 2017. 
55. Batool, A.; Samad, N.; Kazmi, S.S.; Ghufran, M.A.; Imad, S.; Shafqat, M.; Mahmood, T. Spring water quality and human health: An assessment of natural springs of margalla hills Islamabad zone-III. Int. J. Hydrol. 2018, 2, 41-46. [CrossRef]

56. Chandio, S.H.; Ahmed, S.M.; Saleem, W.; Naeem, S.; Bhutto, S.U.A.; Sanjrani, M.A. Assessment of Physical-Chemical Parameters of Water along the Catchment Areas of Rawal Dam Islamabad, Pakistan. Eurasian J. Sci. Eng. 2019, 4, 1-13.

57. Khan, S.A.; Rehman, T.A.U.; Nasir, T.A.; Aftab, S.; Hafeez, A. Assessment of Waste Water Treatment Plant Efficiency through Physico-Chemical Analysis: A Case Study of I-9 Waste Water Treatment Plant, Islamabad, Pakistan. Int. J. Econ. Environ. Geol. 2017, 8, 16-20.

58. Alary, M. Islamabad Water Factory-Constructive Critical Review of Hydrogeological Reports; Nestle Pakistan: Islamabad, Pakistan, 2016.

59. Naeem, S.; Cao, C.; Fatima, K.; Najmuddin, O.; Acharya, B. Landscape Greening Policies-based Land Use/Land Cover Simulation for Beijing and Islamabad-An Implication of Sustainable Urban Ecosystems. Sustainability 2018, 10, 1049. [CrossRef]

60. Hisam, A.; Rahman, M.U.; Kadir, E.; Tariq, N.A.; Masood, S. Microbiological Contamination in Water Filtration Plants in Islamabad. J. Coll. Physicians Surg. 2014, 24, 345-350.

61. Howard, G.; Bartram, J. Domestic Water Quantity, Service, Level and Health; World Health Organization: Geneva, Switzerland, 2003.

62. Wee, R.Y. Countries with the Worst Water Use Productivity. 25 April 2017. Available online: https://www. worldatlas.com/articles/countries-with-the-worst-water-use-productivity.html (accessed on 1 October 2019).

63. Sharma, S. Performance Indicators of Water Losses in Distribution System; UNESCO-IHE: Delft, The Netherlands, 2008.

64. Russo, A.; Cirella, G.T. Modern Compact Cities: How Much Greenery Do We Need? Int. J. Environ. Res. Public Health 2018, 15, 2180. [CrossRef] [PubMed]

65. Berg, C.v.d.; Danilenko, A. The IBNET Water Supply and Sanitation Performance Blue Book; The World Bank: Washington, DC, USA, 2011.

66. ESAWAS. Regional Bemchamarking of Water Supply and Sanitation Utilities 2014/15 Report; Eastern and Southern Africa Water and Sanitation Regulators Association: Lusaka, Zambia, 2016.

67. Likert, R. A technique for the measurement of attitudes. Arch. Psychol. 1932, 22, 55.

68. James, L.D.; Shafiee-Jood, M. Interdisciplinary information for achieving water security. Water Secur. 2017, 2, 19-31. [CrossRef]

69. Margat, J.; Gun, J.v.d. Groundwater around the World A Geographic Synopsis; CRC Press: London, UK, 2013.

70. Bank, W. Economic Impacts of Inadequate Sanitation in Pakistan (English); Water and Sanitation Program Working Paper; World Bank: Washington, DC, USA, 2013.

71. Yi, S.; Ryu, M.; Suh, J.; Kim, S.; Seo, S.; Kim, S.; Bond, H. Smart Water Management: Case Study Report; Korea Water Resources Corporation, International Water Resources Association: Deajeon, Korea, 2018.

72. Jensen, O.; Nair, S. Integrated Urban Water Management and Water Security: A Comparison of Singapore and Hong Kong. Water 2019, 11, 785. [CrossRef]

(C) 2020 by the authors. Licensee MDPI, Basel, Switzerland. This article is an open access article distributed under the terms and conditions of the Creative Commons Attribution (CC BY) license (http://creativecommons.org/licenses/by/4.0/). 